\title{
The Revival of Panpsychism and its Relevance for the Science-Religion Dialogue
}

\author{
Joanna Leidenhag \\ (University of Edinburgh)
}

The dialogue between the natural sciences and theology is frequently complimented by additional dialogue partners, such as historians, poets, literature scholars, and most frequently, philosophers. The goal of this paper is to test both the relevance and fruitfulness of one particular philosophical theory of consciousness for key issues in science-religions dialogue. The philosophical theory in question is panpsychism. This examination of panpsychism within science-religion is timely and relevant because panpsychism is currently undergoing a significant revival in philosophy of mind, and yet the potential impact of this revival for the science-religion dialogue has yet been unrealized.

Panpsychists argue that mentality is fully natural, in that it is fundamental to the universe, but not reducible to the physical. As is shown in the first section of this paper, panpsychism offers itself as a via media between physicalism and dualism. It is worth noting that one type of panpsychism, namely panexperientialism, has had a central role within process theology. Process theology has been a prominent philosophical platform from which to construct the dialogue between science and religion, but it comes with a host of idiosyncratic theological commitments in tow. The impetus for this paper is the substantial revival in panpsychist thought, outside of process metaphysics, from (mostly secular) philosophers of mind, such as Galen Strawson, David J. Chalmers, Thomas Nagel, William Seager, and Philip Goff, to name only a few. This new and growing body of scholarship allows this paper to disentangle panpsychism from the overarching system of process thought, and consider its potential for science and religion independently. ${ }^{1}$

In order to explore the positive impact that panpsychism might have if adopted as a research program within science-and-religion dialogue, this paper explores two test cases: special divine action and theistic evolution. Both of these test cases have been chosen as a result of their prevalence within science-religion dialogue over recent decades. The large quantity of literature addressing divine action and theistic evolution, which cannot be exhaustively dealt

\footnotetext{
${ }^{1}$ For example, panpsychist philosophers can (and most do) maintain a substance-based metaphysic. In addition, a theistic panpsychist need not adopt the God of process theism. That is, a panpsychist theologian is free to hold to a non-bipolar, Trinitarian God of unlimited power who created the world ex nihilo. Indeed, panpsychism does not determine or prescribe any particular doctrine of God.
} 
with in this paper, testify that these areas of research continue to be of great importance and concern to many people. This paper makes an original contribution to these discussions by arguing that contemporary philosophical panpsychism can aid Christian theologians to dialogue with the natural sciences in articulating God's action through quantum phenomena and God's providential guidance of evolution.

That said, if panpsychism is considered entirely incompatible with the relevant scientific disciplines, then few in the science-religion dialogue would offer panpsychism more than a passing and dismissive glance. For example, Philip Clayton curtly rejects panpsychism on the grounds that as "a robustly metaphysical move" it "cuts [itself] off from the evidential considerations that science could otherwise provide."2 Although using the natural sciences to verify or falsify a philosophical framework is always a fraught exercise, some amount of corroborative resonance is a reasonable desideratum. Without such resonance, no amount of theological benefit or philosophical argumentation is likely to persuade scholars working at the forefront of the science-religion to consider panpsychism seriously. In order to counter Clayton's condemnation of panpsychism, therefore, this paper must evaluate the extent to which panpsychism, as a metaphysical hypothesis, is compatible with the principles and provisional conclusions of the scientific disciplines most relevant to these test cases, namely evolutionary biology and quantum physics.

It should be emphasised that at no point does this paper argue that the current state of scientific research strongly supports a panpsychist metaphysic. The argument is only that panpsychism is compatible and can be seen to find some limited, but significant, areas of resonance or traction with the natural sciences. It is undeniable that panpsychism flies in the face of modern intuitions about the non-human world, but then again, so does much in contemporary science. I suggest that the resonance which panpsychism finds with some interpretations of quantum physics and evolutionary biology should be sufficient for scholars within the science and religion dialogue to at least explore the implications for panpsychism for their own field. If science-religion scholars are willing to entertain panpsychism, then it quickly becomes apparent that the potential gains are significant. Indeed, I suggest that if science and religion scholars continue to be committed to articulating non-interventionist theologies of divine action then panpsychism is most promising way forward.

\footnotetext{
${ }^{2}$ Philip Clayton, Mind and Emergence: From Quantum to Consciousness (New York: Oxford University Press, 2004), 130.
} 


\section{Introducing Contemporary Panpsychism}

Panpsychism is not an extremely well-known theory of consciousness within contemporary theology or science-and-religion. However, panpsychism is currently enjoying a significant level of renewed attention by (largely secular) philosophers of mind, as attested to by the rapid rate of publications in this area. ${ }^{3}$ The first task of this paper, then, is to give a brief, somewhat general, description of panpsychism in its contemporary form.

As stated above, panpsychism is the theory that (proto) consciousness, or experience, or subjectivity of some kind is fundamental to the entire universe. ${ }^{4}$ This standard definition comes from leading panpsychists William Seager, Philip Goff and Sean Allen-Hermanson:

Panpsychism is the view that mentality is fundamental and ubiquitous in the natural world. ${ }^{5}$

'Fundamental' here refers to a substance, property or process which is a basic part of our universe, existing for as long as the universe has existed, deriving its existence from nothing else within the universe. To put it another way, Thomas Nagel, whose 1979 essay "Panpsychism" is widely attributed with reigniting interest in the topic, defines panpsychism as "the view that the basic physical constituents of the universe have mental properties." $6 \mathrm{~A}$ fundamental or basic entity is neither emergent through natural processes, nor infused into an organism by divine intervention, but exists as long as the universe has existed. In this way, panpsychism differs from other realist theories of consciousness such as emergence theory, whereby mind emerges from the complexity of matter, or classical substance dualisms, whereby God gifts a soul/mind to some animals upon conception or embryonic development. Most contemporary panpsychists, whilst denying the reality of neither the mental nor the

\footnotetext{
${ }^{3}$ See, for example, the two large edited volumes and monographs on panpsychism published just in the last year; William Seager (ed.), Routledge Companion to Panpsychism (New York: Routledge, 2017); Godehard Brüntrop and Ludwig Jaskolla (eds.), Panpsychism: Contemporary Perspectives (Oxford: Oxford University Press, 2017); David Skrbina, Panpsychism in the West, $2^{\text {nd }}$ ed. (Cambridge, MA: MIT Press, 2017); Philip Goff, Consciousness and Fundamental Reality (Oxford: Oxford University Press, 2017).

${ }^{4}$ In this paper, I see consciousness, experience and subjectivity to be interchangeable concepts. Subjectivity is the capacity for a subjective experience; that is, experience from a first-person viewpoint. Similarly, to be conscious, or to have consciousness, is to have experiences from a first-person perspective. Although a human consciousness (and most likely an animal consciousness) contains additional capacities, volition, rationality, intentionality, self-consciousness etc. I am not presupposing these capacities within the term 'consciousness'. It is because I am referring to the most minimal form of consciousness as experience that the word (proto) is here placed in brackets.

${ }^{5}$ Goff, Philip, Seager, William and Allen-Hermanson, Sean, "Panpsychism", The Stanford Encyclopedia of Philosophy (Winter 2017 Edition), Edward N. Zalta (ed.), URL:

$<$ https://plato.stanford.edu/archives/win2017/entries/panpsychism/>. Accessed: 11/01/18.

${ }^{6}$ Thomas Nagel, Mortal Questions, (Cambridge: Cambridge University Press, 1979), 181.
} 
material, seek to eschew traditional dualisms by underlying that what we call 'material' and 'mental' always come together and cannot be separated.

Whilst panpsychists vehemently deny the emergence of consciousness from the entirely nonconsciousness many emphasise that weaker forms or emergence, or alternative theories of mental combination, must play an important part in the development of consciousness. It is through theories of either emergence or combination that panpsychists avoid implying that all objects (tables, rocks, oceans, whales, higher apes, etc.) in the universe are equally consciousness - which would seem to be a reductio ad absurdum. ${ }^{7}$ In addition, a theistic panpsychist will almost certainly want to say that God infused the universe with soul or mind from the beginning so that this quality of the universe is still attributable to the Creator, to whom we can then express gratitude. Panpsychism does not presuppose that mind is eternal, akin to deity, or uncreated, and so is not to be confused with pantheism or polytheism. ${ }^{8}$ Thus, panpsychism is entirely compatible with traditional forms of monotheism. Whilst panpsychism is compatible in these qualified ways with emergence theory and a divineinfusion model of the origin of consciousness, it seems incompatible with non-realist theories of consciousness (materialism, reductive physicalism, epiphenomenalism, functionalism, etc.).

The question of the relationship between material structures or the physical causal nexus and the immaterial mind has become known as "the hard question of consciousness." As panpsychist philosopher David Chalmers (who posed this question in its contemporary form) asks, "how can physical properties alone give rise to conscious qualia?" 9 This problem is commonly localized to humanity and referred to as 'the mind-body problem'. However, since human bodies arise from, interact with, and return to the dust of the ground and stars, the mind-body problem cannot be limited to a question concerning human beings. Instead, this "hard question" quickly becomes a broader problem of how to locate or understand the phenomenon of experience in the universe at all, given the presupposition the vast majority of the cosmos is purely material and can be mechanistically explained through empirical and

\footnotetext{
${ }^{7}$ This is a wide spread misunderstanding of panpsychism. As David Skrbina has shown in his fairly comprehensive study of the history of panpsychism in Western philosophy, only one or two panpsychists have ever implied anything of this sort. See, Skrbina, Panpsychism in the West.

${ }^{8}$ For a discussion on the relationship of panpsychism to polytheism and pantheism when mentality is identified to divinity see, Yujin Nagasawa, 'Panpsychism versus Pantheism, Polytheism, and Cosmopsychism', William Seager (ed.), Routledge Companion of Panpsychism, Routledge, forthcoming.

${ }_{9}^{9}$ David J. Chalmers, The Conscious Mind: In Search for a Fundamental Theory (New York: Oxford University Press, 1996), 303-305.
} 
reductive means. As Thomas Nagel has argued, if we take the evolution of self-conscious homo sapien's seriously, the mind-body problem "is not just a local problem... but that it invades our understanding of the entire cosmos and its history." 10 The question of consciousness does not just ask, 'what does it mean to be human?', but 'what is the nature of this cosmos in which we find ourselves? Is this truly our home?' As such it is unsurprising that questions of consciousness are never far from the discussions concerning the relationship between science and religion.

\section{Panpsychism and Quantum Physics}

Quantum physics is probably the most conducive discipline within the natural sciences for engagement with speculative metaphysics. Notorious for its ability to support the wild and wacky, one has to exercise some caution when discussing the metaphysics of quantum mechanics; but that does not exclude the possibility of genuine discovery. Physics is sometimes depicted as the most foundational of the natural sciences because the deepest questions physicists seek to answer concern the origins and fundamental nature of the empirical universe. The idea within panpsychism, that consciousness is fundamental throughout the universe, already implies the need for philosophers and theologians to dialogue with physicists regarding the nature of that which is most fundamental. Although physicists such as Thomas Edison and Arthur Eddington arguably held panpsychist views prior to the rise of quantum psychics, the discovery of quantum phenomena seems to add support to the possibility of the proliferation of consciousness throughout the universe. ${ }^{11}$

Early quantum physicist Sir James Jean wrote that "The quantum phenomena make it possible to propose that the background of the universe is mind-like." It is for this reason that "The universe begins to look more like a great thought than a great machine." 12 Another early example of drawing a panpsychist conclusion by employing "Quantum Mechanics as a Basis for Philosophy" comes from J.B.S. Haldane. Haldane, in the aforementioned paper, argued that mind is a "resonance phenomena", associated with the wave-like, rather than particle-

\footnotetext{
10 Thomas Nagel, Mind and Cosmos: Why the Materialist Neo-Darwinian Conception of Nature is Almost Certainly False (Oxford: Oxford University Press), 3.

${ }^{11}$ Paul Carus, "Panpsychism and panbiotism" The Monist 3, 234-257 (243) quotes Thomas Edison: "All matter lives, and everything that lives possess intelligence... The atom is conscious if man is conscious... I cannot avoid the conclusion that all matter is composed of intelligent atoms and that life and mind are merely synonyms for the aggregation of atomic intelligence." Arthur Eddington wrote that, "All through the physical world runs that unknown content, which must surely be the stuff of our consciousness." A. Eddington, Space, Time and Gravitation, (Cambridge: Cambridge University Press, 1920), 200.

${ }^{12}$ James Jeans, The Mysterious Universe (New York: Macmillan, 1931), 158.
} 
like, aspect of atomic phenomena. As a result, he interpreted the tunnelling effect (where an electron can pass through an insulating barrier) as primitive "purposive behaviour". ${ }^{13}$

Haldane's theory captures the basic idea behind many panpsychist interpretations of quantum quandaries. $^{14}$

One version of the Copenhagen interpretation of quantum mechanics, which gives the greatest support to panpsychism, is the theory that the quantum probabilities are reduced to one actuality (referred to as, the wave function collapse), not by uncaused indeterminism, but by the act of measurement. First, this implies a causal relationship between classical apparatus (which does the measuring) and quantum events (which are 'measured'). Second, as further interpreted by physicists such as John von Neumann, Eugene Wigner and John Wheeler, this hypothesis implies a causal relationship between consciousness and wavefunction collapse. ${ }^{15}$ The question arises: what level of consciousness is needed to collapse the wave function and is the collapse ever objective fact? If the complexity of human consciousness in the deliberate act of measurement is required (or if humans are the only conscious beings in the universe), then this implies a strange and excessively anthropocentric conclusion that the universe was indeterminate until twentieth century physicists worked out how to measure quantum probabilities! If consciousness does indeed play a causal role in collapsing the wave function (and of course this is still a very big "if"), then the more plausible conclusion is that there exists a mental nexus through which causation can occur, beyond that of human or animal interactions - indeed, throughout the entire universe.

Perhaps the best developed quantum approach to panpsychism is by physicist Stuart Hameroff and mathematician Roger Penrose. Hameroff and Penrose focus on the uniquely

\footnotetext{
${ }^{13}$ J.B. S. Haldane, "Quantum mechanics as a basis for philosophy", Philosophy of Science 1: 78-98, 89.

${ }^{14} \mathrm{~A}$. Cochran in 1971 wrote that "the quantum mechanical wave properties are actually the conscious properties of matter" so that "atoms and fundamental particles have a rudimentary degree of consciousness, volition, or self-activity." A. Cochran, "The relationship between physics and biology" Foundations in Physics, 1, no.3 235250, 236.Freeman Dyson in 1979 suggested that "mind is always inherent in every electron, and the processes of human consciousness differ only in degree but not in kind from the processes of choice between quantum states which we call "chance" when they are made by electrons." F. Dyson, Disturbing the Universe (London: Harper \& Row, 1979), 249. Even more philosophically, Danah Zohar in 1990 wrote that "the wave/particle duality of quantum 'stuff' becomes the most primarily mind/body relationship in the world." D. Zohar, The Quantum Self, (New York/London: Bloomsbury, 1990), 80.

${ }^{15} \mathrm{John}$ von Neumann first proposed this surprisingly resilient interpretation of the measurement phenomenon in the nineteen-thirties. Whereas Eugene Wigner interpreted the role of consciousness in the wave collapse as solipsism, John Wheeler saw it as an indication that we live in a "participatory universe"; one than cannot be accurately described without factoring in our own subjective involvement. The idea that reality is participatory has grown (moderately) in popularity in recent years. For a recent introductory level discussion of these issues see, Philip Ball, "Conscioulsy quantum: How to make everything real”, New Scientist Is. 3151, (Nov. 2017), 29 32.
} 
non-algorithmic collapse of superimposed quantum events within the non-algorithmic intuition and problem-solving capacities of the human brain. By focusing on the collapse of quantum events within the human brain, Hameroff and Penrose moved the relationship of consciousness-to-collapse from that of an external observer (the scientist or measurement equipment) to the quantum event itself. This "objective reduction" from the quantum phenomena (rather than a 'subjective' external observer) entails a form of panpsychism. Hameroff concludes that "perhaps panpsychists are in some way correct and components of mental processes are fundamental, like mass, spin, of charge." 16

However, the Copenhagen interpretation is not the only possible way of understanding the weird and wonderful world of quantum physics. One alternative is the more determinist "Hidden-Variables" interpretation, proposed by David Bohm. Bohm suggests that there are hidden variables throughout the universe to which scientists do not yet have access, and which explain the seemingly random behaviour of quantum particles/waves. Surprisingly, Bohm also endorsed a form of panpsychism. ${ }^{17}$

Bohm argued that there is a "guiding wave" or "pilot wave" throughout reality which determines quantum behaviour (such as determining which slit a particle passes through in the dual-slit experiment). Bohm went on to argue that the guiding wave points towards an "implicate order", which "applies to both matter and to consciousness." 18 Bohm defends a unified monistic worldview whereby "consciousness and matter in general are basically the same order (i.e. the implicate order as a whole)." ${ }^{19}$ Bohm suggests that this implicate order is governed by information content. Bohm argues that "the notion of information [is] something that need not belong only to human consciousness, but that may indeed be present in some sense, even in inanimate systems of atoms and electrons". ${ }^{20}$ The idea that the underlying nature of reality is informational has become increasingly popular. When combined with

\footnotetext{
${ }^{16}$ S. Hameroff, "Funda-mentality: Is the conscious mind subtly linked to a basic level of the universe?", Trends in Cognitive Science 2, no.4, 121; cf. S. Hameroff "More neural than Thou", in Toward a Science of Consciousness II, ed. S. Hameroff et al. (MIT Press, 1998).

${ }^{17}$ Appealing to the idea the argument for panpsychism from continuity Bohm argues, "That which we experience as mind. . . will in a natural way ultimately reach the level of the wavefunction and the 'dance' of particles. There is no unbridgeable gap or barrier between any of these levels. . . It is implied that, in some sense, a rudimentary consciousness is present even at the level of particles physics." David Bohm, "A new theory of the relationship of mind and matter", Journal of the American Society for Psychical Research 80, no.2, 131.

${ }^{18}$ David Bohm, Wholeness and the Implicate Order, (London: Routledge, 1980), 196.

${ }^{19}$ Bohm, Wholeness , 208.

${ }^{20}$ David Bohm, "A new theory of the relationship of mind and matter", Journal of the American Society for Psychical Research 80, no.2, 124-125.
} 
GiulioTononi's idea of integrated information theory, which argues that complex consciousness in the brain arises out of the integration between information states, these ideas point towards a possible panpsychist solution to the mind-body problem. ${ }^{21}$ This also shows that a panpsychist theory of consciousness in no way needs to undermine the importance of neurology and neuroscience for understanding animal consciousness.

More recently, polymath and religious naturalist Stuart A. Kauffman, best known in the science-and-religion dialogue for his development of systems based thinking, published both an article in Theology \& Science and a monograph in 2016, which changes his position on consciousness from that of strong emergence to that of panpsychism. ${ }^{22}$ Kaufmann's main contribution in this recent work has been to outline the potential impact that Bohm's panpsychist interpretation of quantum physics has by reintroducing soul-talk into scienceand-religion and positing the existence of a cosmic mind. What is striking about this argument is that Kaufman's new and unorthodox position arises as an interpretation of the mathematical and experimental evidence of quantum physics and Kauffman clearly articulates his concern over the "testable" (and non-testable) aspects of his proposal. ${ }^{23}$

Kauffman's argument for panpsychism results from an interpretation of quantum theory, whereby measurement, and therefore mind, mediates potentialities (which as Schrödinger's cat thought experiment illustrates, do not obey the law of the excluded middle) into actualities (which do obey the law of the excluded middle) at the quantum level. If measurement requires mind (consciousness, free-will and intentionality), and quantum events are mediated by measurement, unless the universe was in a state of complete superposition and indeterminacy until the emergence of a conscious organism, then this argument clearly supports panpsychism. Kaufman writes,

Thus, perhaps measurement is mediated by mind at many levels- perhaps down to the idea that quantum variables can measure one another, perhaps consciously and with free will...Here is a vast participatory

\footnotetext{
${ }^{21}$ This solution is currently supported by leading neuroscientist Christoph Koch and philosophers such as David J. Chalmers and Gregg Rosenberg. See, Christof Koch, "In which I argue that consciousness is a fundamental property of complex things", (Cambridge, MA: MIT Press, 2014); David J. Chalmers, The Character of Consciousness (Oxford: Oxford University Press, 2010); Gregg Rosenberg, "Land Ho? We Are Close to a Synoptic Understanding of Consciousness", Panpsychism: Contemporary Perspectives (eds.) Godehard Brüntrop and Ludwig Jaskolla (Oxford: Oxford University Press, 2017), 153-177.

${ }^{22}$ Stuart A. Kauffman, “Cosmic Mind?” Theology and Science, (2016) 14:1, 36-47; Stuart A. Kauffman, Humanity in a Creative Universe (Oxford: Oxford University Press, 2016).

${ }^{23}$ Kristi Keller, "Response to Stuart Kauffman: The Cosmic Mind and NIODA", Theology and Science (2016) 14.1, 54-58; Kauffman, “Cosmic Minds?”, 36, 38, 40, 43, 45.
} 
panpsychism, in which something like cosmic mind or minds become thinkable. ${ }^{24}$

If credible, Kauffman's highly speculative proposal offers some significant advantages. Kauffman argues that his panpsychist interpretation of quantum mechanics offers a single elegant explanation for the double-slit experiment, the "entangled variable", of non-local and non-causal interaction (the famous Einstein-Podolsky-Rosen experiment), and the relationship between quantum and classical physics. Whilst interpretations of quantum physics all remain highly contested, the support from respected physicists and the interpretative resonance which panpsychism finds within this field is startlingly strong. What then might all this mean for theology and the science-religion dialogue? For this, we turn to the first test case: special divine action.

\section{Test Case 1: Special Divine Action}

One of the most substantial collaborative research projects within the contemporary field of science and religion focused specifically on the issue of divine action. The sustained research between The Vatican Observatory and The Centre for Theology and the Nature Sciences resulted in five edited volumes, containing 91 chapters from 51 authors, with the shared subtitle Scientific Perspectives on Divine Action. The large scale of this project has meant that this work has dominated discussions and framed much of the methodology within the relatively new discipline of science-and-religion more widely. Almost a third of the chapters published as a result of this research sought to draw interpretations of quantum mechanics into theological discussion. It is, therefore, widely accepted that philosophical interpretations of quantum mechanics are of significance for the science-religion community, particularly regarding the question of how God acts in the world. The theory of ontological indeterminism (Heisenberg's interpretation) has dominated the field of science and religion, largely as a result of the contributions from Robert J. Russell. However, since panpsychism remains a viable implication of quantum physics, as well as receiving attention from philosophers of mind, it is important for theologians to consider the implications of a panpsychist interpretation of quantum mechanics for models of divine action. In particular, panpsychism deserves equal and serious attention as one way of framing God's interaction within creation, in discrete times and places to make a genuine causal difference (special divine action).

\footnotetext{
${ }^{24}$ Kauffman, “Cosmic Minds?”, 38.
} 
Russell's proposal broadly argues that because quantum events are ontologically indeterminate, God can choose which way the wave function collapses without violating the principle of energy conservation, interrupting causal closure or undermining the determined nature of physical events at the level of classical physics. There are a number of potential problems within Russell's proposal, ${ }^{25}$ but for the sake of brevity I will focus on one important question that arises: How much or how frequently does God resolve quantum probabilities into actualities? Arthur Peacocke suggests that if God always and in all ways determines quantum events, and these events impact upwardly upon the manifest world, then Russell's proposal cannot escape the charge of occasionalism. ${ }^{26}$ However, John Polkinghorne has pointed out that if God only determined a few quantum events - because not all quantum events are indeterminate enough to allow God to act without breaking causal closure - then Russell's account of divine action is an insufficiently "episodic account of providential agency." 27

In response to this challenging question Russell, following Nancey Murphy, argues that God is active in all quantum events, but not in an all-determining fashion. ${ }^{28}$ Since God is not acting in an all-determining fashion, Russell's proposal cannot be accused of occasionalism. Similarly, because God is seen to act in every quantum event, then this is not as woefully episodic as Polkinghorne fears. Instead, Russell writes that this model involves "a continuous creative (divine) presence within each (quantum) event, co-determining the outcome of these elementary physical processes." 29 Russell has successfully avoided both Peacocke's and Polkinghorne's challenges, but in so doing has created a new question: What is the "within" that becomes essential for allowing God to act in a non-determining and co-operative manner as the quantum level?

How is the "within each (quantum) event" to be understood in Russell's proposal of divine action? It seems unlikely, given the non-material nature of divine presence and from what we know of quantum particles/waves, that this can be interpreted in a spatial way, like how a gas

\footnotetext{
${ }^{25}$ See, Nicholas Saunders, Divine Action and Modern Science, (Cambridge: Cambridge University Press, 2002), chapter 6.

${ }^{26}$ Arthur Peacocke, “God's Interaction with the World: The Implications of Deterministic 'Chaos' and of the Interconnected and Interdependent Complexity", Chaos and Complexity: Scientific Perspectives on Divine Action, (ed.) Robert J. Russell, Nancey Murphy, and Arthur Peacocke (Vatican State/ Berkeley, CA: Vatican State Observatory/ Center for Theology and the Natural Sciences, 1995), 279-281.

${ }^{27}$ John Polkinghorne, Science and Creation, 58; Science and Providence, 27-28; Reason and Reality, 40-41.

${ }^{28}$ Robert J. Russell, Cosmology: From Alpha to Omega (Minneapolis: Fortress Press, 2008), 154; Nancey

Murphy, "Divine Action in the Natural Order" Chaos and Complexity, 340-342.

${ }^{29}$ Russell, Cosmology, 156. Italics added.
} 
can be within a jar by taking up the space within the jar. Moreover, a literally spatial interpretation of Russell's proposal here gives no aid to understanding the conundrum of divine-creaturely co-determination. And yet the language of God working within the universe, within creatures, and within creaturely action is one which many find intuitively helpful and meaningful. A better interpretation of such language would be to posit that quantum particles/waves have a non-spatial "within" by virtue of having mental experiences. This is how we commonly use the word "within" when referring to God's presence within human beings, or when stating that the mind resides "within" the brain/body.

This experiential usage of the term "within" evokes a comparison to the uniquely direct and intimate relationship between the mind and the brain, or between God and the mind of a Christian believer. In this way, Russell's use of the word "within" could be extended to draw upon the concept of the indwelling of the Holy Spirit. In Scripture and the collective experience of the Church the indwelling of the Spirit is a hidden, mystical, but also experiential presence. Although I have not found any suggestion in Russell's own work of a connection between the 'within' of the indwelling of the Holy Spirit in Christian spirituality and his own articulation of God acting 'within' quantum events, it is a connection which could be a great theological resource to his proposal.

A panpsychist ontology is a way of articulating that all things have a "within". Without this panpsychist ontology, without a 'within' for God to indwell, any statement on Russell's (and Murphy's) account of co-operation between elementary physical processes and Divine agency can only be poetic wordplay. The movement (spin, charge, direction, probabilities) of a quantum particle/wave, understood materialistically, cannot be co-operative with, but can only be co-opted by, God. It is unlikely that "co-determining" outcomes is possible when there is only one active agent (and in particular, when that sole agent is the Divine Creator). If there is no objective "within" and no genuine co-determination, then Russell's proposal cannot escape the charges of occasional or episodic intervention outlined above.

Panpsychism, which posits a genuine "within" in terms of subjectivity or experience, provides the possibility of genuine co-operation or co-determination even at the quantum level.

The theologian who has perhaps done the most to elucidate a form of divine-creaturely cooperation through subjectivity is Philip Clayton, best known for his theology of emergence theory. For Clayton "God must persuade the agent in question to act in a particular way for 
the event to occur." 30 This concern for creaturely persuasion and participation seems to arise chiefly in response to the moral charges against interventionism; the concerned to avoid a divine invasion, which violates nature or interrupt the causal nexus. As Clayton highlights, divine persuasion presupposes creaturely subjects. Clayton writes, "[t]his [divine persuasion], again, implies a special role for mental causes...Intentional agents can be persuaded, whereas (as far as we know) rocks cannot be persuaded to act on their own, no matter how good the arguments." 31 It is far easier to dismiss a unified "rock-consciousness" (which no panpsychists I have read support) than it is to rule out the possibility of a quantum-level nexus of experience and subjectivity which God may influence in a persuasive manner.

Since Clayton champions strong emergence theory, where mental cause and properties only emerge at a higher (neurological) level of the natural world, Clayton concedes that his proposal "limits the efficacy of the divine will in the world" because "this result makes it difficult to conceive a divine influence on rocks or other purely physical systems apart from the laws and initial conditions established by God at creation." 32 Clayton's strong emergence theory means that special divine action is limited to the mental realm and can only impact the material world via human (or higher-animal) mediation. The result of Clayton's proposal is the view that God was unable to interact with creatures and truly locked "outside of" creation for billions of years. This is a proposal that many will find unhelpfully anthropocentric, in that God needs human beings as mediators if God is to impact the natural world, and more widely contrary to both the sovereignty and relational nature of God.

In contrast to Clayton, the main advantage of the quantum model for special divine action is due to the fundamental and ubiquitous nature of quantum events/particles/waves: "God is active everywhere in space and time in relation to $\psi$ as it extends throughout space and evolves in time." ${ }^{33}$ Locating divine action in quantum events means that theologians can account for the pervasiveness of divine action in the billions of years prior to the phenomenon of life, and God can be just as effective in the far reaches of the universe as on planet earth. Thus, a panpsychist quantum account of divine action can avoid the threats of

\footnotetext{
${ }^{30}$ Philip Clayton, "Natural Law and Divine Action: The Search for an Expanded Theory of Causation", Zygon vol.39, no.3 (September 2004), 615-636, 628.

${ }^{31}$ Clayton, "Natural Law and Divine Action", 628.

32 Clayton, "Natural Law and Divine Action", 628.

${ }^{33}$ Russell, Cosmology, 184.
} 
interventionism (as well as occasionalism and episodic intermissions), whilst additionally providing an objective and causal understanding of omnipresence.

On the basis of this unique fundamentality of quanta, Russell argues that "quantum physics contributes a necessary - thought not a sufficient- piece to the explanatory puzzle of how God acts in the world." ${ }^{34}$ In particular, Russell emphasises that his model is not sufficient for articulating "divine active in personal experience and human history, because that is primarily where we, as persons of faith, encounter the living God." ${ }^{35}$ For this, he argues, we need to look more closely at the level of mind and persons. But Russell notes that "we will eventually need to work out the detailed relations between these [quantum based and personal] models by integrating them into a consistent and coherent, adequate and applicable metaphysical framework." 36 The best metaphysical framework currently available for relating top-down mental causation and quantum mechanics seems to be something like panpsychism; God interacts with minds throughout the universe, from the most unimaginably simple mentality of a quantum particle/wave, to the sophisticated self-consciousness of a human person.

\section{Panpsychism and Evolutionary Biology}

The second area of natural science from which panpsychists commonly seek to draw support is evolutionary biology. Although evolutionary biology has greatly developed since Charles Darwin published his Origin of the Species in 1859, the underlying principle of continuity between species remains largely unchallenged. It is, therefore, still of interest that some early evolutionary theorists, professed panpsychist beliefs on the basis of this continuity between all things.

A significant number of historically renowned scholars (such as Ernst Haeckel, William Kingdon Clifford, Herbert Spencer and Morton Price) saw Darwin's theory of evolution to support a philosophy of panpsychist monism. ${ }^{37}$ However it is William James (1842-1910)

\footnotetext{
${ }^{34}$ Robert J. Russell, "Quantum Physics in Philosophical and Theology Perspective”, Physics, Philosophy and Theology: A Common Quest for Understanding, (eds.) Robert J. Russell, William Stoger S.J., and George Coyne, S.J. (Vatican State: Vatican Observatory, 1988).

${ }^{35}$ Russell, Cosmology, 159.

${ }^{36}$ Russell, Cosmology, 159.

${ }^{37}$ For more on how these historical figures expressed that panpsychist views see, David Skrbina, Panpsychism in the West, 131-133, 141-150.
} 
who gives panpsychism one its most famous treatments, which continues to influence panpsychist philosophers today. In Principles of Psychology, James wrote,

If evolution is to work smoothly, consciousness in some shape must have been present at the very origin of things. Accordingly, we find that the most clear-sighted evolutionary philosophers are beginning to posit it there. Each atom of the nebula, they suppose, must have had an aboriginal atom of consciousness linked with it. Some such doctrine...is an indispensible part of a thorough-going philosophy of evolution. ${ }^{38}$

This is a clear statement of what panpsychists philosophers call 'the argument for panpsychism from continuity', which as a theory of monism seems to find traction with the underlying principle of continuity within evolution. It is worth noting that the argument from continuity, whilst in opposition to a purely emergence based theory of consciousness (whereby the higher-levels of reality emerge to create, as if miraculously out of nothing, wholly different kind of phenomena), does uphold a layered view of the natural world. That is, panpsychism upholds the reality of nature's levels and layers of complexity, within a continuous unbroken spectrum of material-mental reality.

As James expressed well, panpsychism is a "philosophy of evolution", found at the interface of metaphysics and speculative biology, and not an easily testable hypothesis. The basic principle is that, if the outcome of evolutionary is psycho-physical (humanity), then the constituents and very process of evolution will also be psycho-physical. ${ }^{39}$ One consequence of panpsychism, when taken as the metaphysical implication of evolutionary continuity, is the humanity cannot be considered utterly, radically, or ontologically unique by virtue of human consciousness (rationality, mind, or a soul). Although panpsychism still holds that humans have a distinct and quantifiably different consciousness to other creatures, theological arguments regarding human uniqueness (in a stronger, qualitative, sense) will have to be grounded elsewhere.

Perhaps one of the most well-known panpsychists within the science-religion dialogue is the French Jesuit palaeontologist, Peirre Teilhard de Chardin. Teilhard took the continuity of evolutionary theory to mean that,

we are logically forced to assume the existence in rudimentary form... of some sort of psyche in every corpuscle, even in those (the mega-molecles

\footnotetext{
${ }^{38}$ William James, Principles of Psychology (Dover, 1890/1950), 149.

${ }^{39}$ Nagel, Mind and Cosmos, 8, 14-15, 46-47, 52-53.
} 
and below) whose complexity is of such low or modest order as to render it (the psyche) imperceptible. ${ }^{40}$

Teilhard even characterized the process of evolution as "the movement of consciousness veiled by morphology", which lead him to his famous "great law of complexity and consciousness". ${ }^{41}$ It is this panpsychist law that gives the universe a "psychically convergent structure or curvature." ${ }^{42}$ Teilhard, of course, goes on to synthesize evolution with Christian eschatology and so to convert his philosophy of panpsychism into a theology of "panChristism". ${ }^{43}$ Whatever one thinks of Teilhard's overarching project, it is noteworthy that for Teilhard's vision of evolution, panpsychism is the necessary bridge to Christian theology and the ontology on which theistic evolution can be most robustly supported.

More recently, an increasingly number of biologists are exploring the possibility that natural selection may only be one means amongst many in which evolution occurs. Other forces, such as genetic drift (particular in small populations), endogenous factors whereby internally selection is collective achieved, Thompson's "laws of form" and Kauffman's "order for free", ${ }^{44}$ sexual selection, genetic assimilation, and genetic accommodation may be equally important for species survival in different circumstances. ${ }^{45}$ These other mechanisms by which evolution may take place compliment (and do not replace) the theory of natural selection. However, it is important to note that most of these means of evolution imply a level of teleology, and with teleology a limited sense of agency or experience already present within evolving organisms. Biologist Tam Hunt, for example, argues that a general theory of how evolutionary change occurs may need to presuppose the power of expectation (as in the expected reproductive fitness of a possible sexual partner) and agential selection to be widespread throughout the natural world and universe. He describes this as "a panpsychist extension of Darwin's theory of sexual selection which explicitly recognizes the role of mind at all levels of nature and which may play the part of a general theory of evolution better than natural selection theory." 46 One can also see in Thomas Nagel's controversial book Mind and

\footnotetext{
${ }^{40}$ Pierre Teilhard de Chardin, The Phenomena of Man (trans.) Bernard Wall, (New York: Harper Perennial, 1955), 301-302.

${ }^{41}$ Teilhard, Phenomenon of Man, 167, 300ff.

42 Teilhard de Chardin, Phenomenon of Man, 61; Christopher F. Mooney, Teilhard de Chardin and the Mystery of Christ, (London: Collins, 1966), 200.

${ }^{43}$ For "pan-Christicism" see Teilhard de Chardin, Science and Christ, (trans.) René Hague 59, 124.

${ }^{44}$ Stuart A Kauffman, The Origins of Order: Self-organization and Selection in Evolution (New York: Oxford University Press, 1993); D’Arcy W. Thompson, On Growth and Form: an Abridged Edition (Cambridge: Cambridge University Press, 1961).

${ }^{45}$ Tam Hunt, "The Middle Way of Evolution", Communicative and Integrative Biology 5.5 (2012), 409.

${ }^{46}$ Hunt, "The Middle Way of Evolution", 408.
} 
Cosmos: Why the Materialist Neo-Darwinian Conception of Nature is Almost Certainly False a philosophical argument for a "postmaterialist theory" of evolution. Put simply, Nagel argues that if evolution brought about consciousness, then evolution cannot be "just a physical process", but "may have to be something more than physical all the way down."

Famously, biologist Simon Conway Morris' theory of convergence has led him to suggest that panpsychism is not only philosophically plausible, but is an empirically justifiable (but not verifiable) claim. Convergence refers to the phenomenon whereby species, which are not closely genetically related, evolve similar traits as a result of having to adapt to similar environments or ecological niches. Common examples include the flight and wings of birds, insects, pteosuars and bats, as well as aspects of the lens within the eye, which seems to have evolved to be very similar through very different genetic dynasties. One way of interpreting this phenomenon is to suggest some form of teleology, either overarching the process of evolution or within organisms in the form of striving. The latter of these two interpretations in particular amounts to a form of panpsychism. ${ }^{48}$ Based on his observations of the behaviour of non-neurologically endowed protistans and dinoflagellates, Conway Morris keeps an open mind on just how far down the evolutionary bush consciousness goes, and speaks with more confidence of "feeling" in sponges and consciousness in insects. ${ }^{49}$ Very few biologists would currently claim to believe in anything like panpsychism. This may be due to a widespread misunderstanding that panpsychism is a form of vitalism. For the sake of brevity, I am only able to state that the two theories are completely distinct. However, there does seem to be a historical and a well-reasoned trend amongst evolutionary theorists to find panpsychism strangely appealing.

\section{Test Case 2: Theistic Evolution}

Undeniably the most fraught and politically explosive issue in the dialogue between Christian theology and the natural sciences is the question of 'creation versus evolution'. The either/or nature of this question has had an unprecedented impact on created the modern myth that

\footnotetext{
47 Thomas Nagel, Mind and Cosmos, 46.

48 The former interpretation may also imply a form of panpsychism known as cosmopsychism, where the universe as a whole is conscious in a minimal or non-complex/ non-integrated sense. See, Goff, Consciousness and Fundamental Reality.

49 Simon Conway Morris, Ruins of Evolution: How the Universe Became Self-Aware, (Templeton press, 2015) 237-238, 246-251. Again, Morris asks the continuity question: "It is customary to speak of intelligence as 'emerging', but if that is the case, where exactly are the thresholds - and if they exist, are they gradual or abrupt? Or could this be completely back to front? Suppose mind is not only independent but also pre-existent to matter?" Morris, Ruins, 286.
} 
science and religion are always and in all matters diametrically opposed. Therefore, the second test case discussed in this paper is the question of theistic evolution: How does belief in God as both Creator and Providential Ruler relate to our understanding of the randomness and mechanism of natural selection in evolution?

The theory of Intelligent Design argues that natural causes and material mechanisms (randomness, impersonal laws of selection, and a vast amount of time) are insufficient in explaining all life within the universe. Proponents of Intelligent Design argue that naturalistic explanations need to be complimented by a non-evolved intelligence of some sort, most frequently a Divine intelligence. ${ }^{50}$ Most scientists (and others) vehemently reject the idea of a non-evolved intelligence as a scientific hypothesis, not least because design arguments often rely upon non-empirically verifiable sources, most notably scripture texts and human intuition. Moreover, the idea that God designed the various stages of evolution faces a significant difficulty in accounting for seemingly "botched and bungled" history of development. ${ }^{51}$ Instead of a perfectly executed grand design, evolution looks more like a long process of trial-and-error, with vast amounts of waste and suffering endured along the way. If God only inputs information (designs) at certain pivotal moments in evolution (such as the emergence of metabolic systems or conscious awareness) then this approach easily slides into a God-of-the-gaps form of argumentation: the gaps in our scientific knowledge, where natural selection seems unable to explain jumps in evolution (such as irreducible complexity or the Cambrian explosion), are cited as the places where we can best see God's direct design and interventionist impact. The danger of this approach is not only to greatly increase the problem of evil, but to risk making theology decreasingly relevant as the natural sciences advance.

Theistic evolutionists differentiate their proposal from Intelligent Design by arguing that God does not interrupt or intervene directly to implement perfectly and completely designed creatures, but that God guides and acts within the whole process in a non-coercive fashion. For some theistic evolutionists, God can be said to permit suffering and waste as a part of evolution in a way that may appear pointless and unjustified to the human conscience. However, God is permitting, rather than designing or orchestrating this tragedy. For other theistic evolutionists, God does not even have a choice in overseeing this painful state of

\footnotetext{
${ }^{50}$ William A. Dembski and Michael Ruse, "General Introduction", Debating Design: From Darwin to DNA, (eds.) William A. Dembski and Michael Ruse (Cambridge: Cambridge University Press, 2004/2006), 3. ${ }^{51}$ David Hume, [1779] "Dialogues concerning natural religion" in Hume on Religion, ed. R. Wollheim, (London, Fontana, 1963), 140.
} 
affairs. What is a shared concern for theistic evolutionists is to minimize direct divine responsibility for suffering by emphasising the self-creative power and freedom which God grants to creation.

John Polkinghorne succinctly defines the concept of theistic evolution as, "divine intervention within unfolding evolutionary process." 52 Thus, theologians such as John F. Haught, Arthur Peacocke, Keith Ward and Polkinghorne himself, all prefer to speak of God's allowing creation the autonomy to evolve according to natural principles, thus allowing for the possibility of mistakes and suffering, whilst also guiding these natural principles in a cooperative and improvisational manner. ${ }^{53}$ Theistic evolutionists imply that if we get our doctrine of God correct - that is, as loving and self-giving, rather than controlling and coercive - then Christians need not fear the advancing understanding of evolutionary biology and theologians can provide some partial response to the problem of evil in the natural world.

One can see the strong link between theistic evolution and the non-interventionist models of divine action of Russell and Clayton examined above. The guiding methodological principles are very much the same; theology and natural science can be integrated if God indirectly persuades, rather than directly interrupts, the forces and entities that the natural sciences model. Therefore, it is unsurprising that a similar question emerges out of theistic evolution as did out of Russell's quantum model of divine action: What does it mean for God to persuade, co-operate with, and work "within" mindless material entities and evolutionary forces? If, as emergence theory claims, the first ten to fourteen billion years of the universe held no teleology, no experience, no agency, then God's persuasion in evolution over this time period amounts to direct causation. ${ }^{54}$ An agent cannot interact with a totally mindless, non-agent in a way that makes a causal difference, by any other means than directly causing or forcing it to act in a way different to how it would have acted automatically (and the object involved is none the wiser either way). A helpful analogy may be the comparison between a car without a driver which is programmed to take passengers to a destination, and a car with a human driver. ${ }^{55}$ Both cars can negotiate various trials and obstacles along the way, but only

\footnotetext{
52 John Polkinghorne, “The Inbuilt Potentiality of Creation”, Debating Design: From Darwin to DNA, (eds.) William A. Dembski and Michael Ruse (Cambridge: Cambridge University Press, 2004/2006), 258. Italics in original.

53 Polkinghorne, “The Inbuilt Potentiality of Creation”, 257; Arthur Peacocke, God and the New Biology, (London: Dent, 1986), 98.

${ }^{54}$ As far as we known carbon-based life appears after ten billion years and self-conscious life after fourteen billion years. John Polkinghorne, "The Inbuilt Potentiality of Creation", 246.

${ }^{55}$ I am grateful to Mikael Leidenhag for this analogy.
} 
the car with a human driver can be persuaded to take a different route or reach a different destination. ${ }^{56}$ In order for the driver-less car to change a destination, a higher intelligence would have to re-program or re-design the system by inputting new information; this is analogous to how intelligent design theorists understand God's providential care of evolution.

The idea that primordial consciousness is an essential ingredient for theistic evolution, if it is to be a genuine alternative to materialistic neo-Darwinianism and Intelligent Design, is hinted at by many of its main proponents. For example, John Polkinghorne argues that "continuous creation" entails that the natural world is open to the actions of agents, both creaturely and divine. Theistic evolution, according to Polkinghorne, pictures God as acting according to this universal openness to agency, balancing divine influence with creaturely autonomy. For Polkinghorne, the question facing theistic evolution is "the theological problem of grace and free will, now writ large." ${ }^{57}$ Similarly, Holmes Rolston III placed the importance of creaturely experience at the centre of his vision for continuous creation. He writes,

The notion of a Newtonian Architect who from outside designs his machines, borrowed by Paley for his Watchmaker God, has to be replaced (at least in biology, if not also in physics) by a continuous creation, a developmental struggle in self-education, where the creatures through 'experience' becomes increasingly 'expert' at life. ${ }^{58}$

For these visions of continuous creation to be meaningful, the roots of experience and agency need to reach deeper than higher-level animals to the very beginnings of cosmic evolution. Keith Ward suggests that the "main strength" of theistic accounts of evolution is that theists "seek to take into account the facts of consciousness and experience in an integrative, purposive explanation." 59 Similarly, the argument for panpsychism from continuity (outlined above) argues that it is difficult to support the claim that mindless, blind, and empty natural processes have the resources to ever produce consciousness and experience (comparisons to the emergence of physical properties such as liquidity, and even the emergence of metabolic life, are false analogies). Therefore, some proto-consciousness or minimal form of mental properties are either injected at some point in evolution by an outside Mind, as an intelligent

\footnotetext{
56 This is not to imply that evolution as a whole needs to take on a single consciousness or agential power, as this analogy could be taken to imply. It is only meant to demonstrate that consciousness of some kind is required for persuasion.

57 Polkinghorne, "The Inbuilt Potentiality of Creation", 258.

${ }^{58}$ Holmes Rolston III, Science and Religion (New York: Random House, 1987), 131.

${ }^{59}$ Keith Ward, “Theistic Evolution”, Debating Design: From Darwin to DNA, (eds.) William A. Dembski and Michael Ruse (Cambridge: Cambridge University Press, 2004/2006), 274. It should be noted that Keith Ward adopts a "dual-aspect idealism", which is in fact a form of panpsychism. Keith Ward, More Than Matter: Is there more to life than molecules? (Grand Rapids, MI: William B. Eerdmans, 2010).
} 
design proponent might argue, or a basic form of these properties existed since the beginning of the universe, and alongside material complexity has been coaxed into development by a gentle and loving God. The latter is a panpsychist version of theistic evolution.

John F. Haught is perhaps the most explicit proponent of a panpsychist theistic evolution. Haught rejects the idea, which he suggests is presupposed by both Darwinian materialists and Intelligent Design theorists, that evolution entails materialism. ${ }^{60}$ Instead, Haught argues that, "in some sense the created world must be self-actualizing, and even self-creative... Any other kind of world, in fact, is theologically inconceivable." ${ }^{\prime 1}$ Haught is explicitly influenced by the writings of Alfred North Whitehead and Teilhard de Chardin, both of whom argued that the only way to articulate Divine presence and guidance throughout and within the entire universe is to posit interiority in all things. ${ }^{62}$ Yet, Haught - like many in contemporary science and religion dialogue - cannot swallow all of the aspects of Whiteheadian and Teilhardian thought. It is for this reason that the contemporary scholarship on panpsychism in philosophy of mind - which is neither Whiteheadian nor Teilhardian (nor Hegelian), should be of great interest and aid for science and religious scholars.

A panpsychist interpretation of theistic evolution allows scholars to make the theological moves which many see as imperative for the integrative project of science and religion. Panpsychism allows God to non-coercively guide evolution in a non-interventionist manner, which is beyond the sphere of empirical investigation, and therefore, cannot be confused as a faux-scientific hypothesis. If creation is imbued with subjectivity and the capacity to experience (in a minimal and basic way), then the language of self-creativity, prior to the emergence of autopoiesis and life, becomes a more robustly meaningful concept. This provides theological rational for the first ten-fourteen billion years of the universe, during which God is neither absent nor inactive in space and time, but as engaged as God has always been and continues to be, in a loving relationship with a creation yet imperfect and incomplete.

\footnotetext{
${ }^{60}$ John F. Haught, "Darwin, Design, and Divine Providence", Debating Design: From Darwin to DNA, (eds.) William A. Dembski and Michael Ruse (Cambridge: Cambridge University Press, 2004/2006), 236. ${ }^{61}$ John F. Haught, "Darwin, Design, and Divine Providence", 243. Elsewhere, Haught writes that "we might wonder what reasonable alternatives could possibly be left available for a theology of evolution" if panexperientialism is rejected; John F. Haught, God After Darwin: A Theology of Evolution, $2^{\text {nd }}$ ed. (Boulder, CO: Westview Press, 2008), 174.

${ }^{62}$ See for example, Haught's use of Whitehead and Teilhard in his chapter "Cosmic Evolution and Divine Action" in God after Darwin, 173-192.
} 


\section{Conclusion}

The revival of panpsychism within contemporary philosophy of mind may be a highly significant development for Christian theologians engaged in the field of science and religion. ${ }^{63}$ By disentangling a theory of fundamental experience or subjectivity from its previous historical and theological associations, contemporary panpsychism offers scholars a new picture of the universe as open at every point to the influence and direction of a loving, non-coercive, but Almighty and Trinitarian Creator. For scholars who consider the deterministic and causally closed view of the world put forward by the materialist and mechanistic philosophy of science to be a challenge to the Christian faith, panpsychism offers a promising way forward. For theologians who wish to speak of God persuading and cooperating with the natural world, but do not wish to limit God's actions to a tiny fraction of space-time, panpsychism seems unavoidable.

Panpsychism offers an enchanted and value-laden picture of the cosmos and roots humanity deep within our native universe; this is our home, even our souls arise from the dust of the earth. With no mysterious ontological jumps (such as in emergence theory), human consciousness is decisively not to be confused with divinity and remains inseparable from embodiment. This is a view of consciousness which should be of interest not only to contemporary philosophers of mind but also to theologians within the field of science and religion and beyond. Whilst the natural sciences cannot verify absolutely any one metaphysic, it has been shown above - perhaps to the surprise of many - that panpsychism finds some resonance and traction with popular interpretations of quantum physics and some philosophical principles of evolutionary biology. The scientific credentials of panpsychism should not be overstated; most scientists still favour a materialistic view of reality. However, the results of this paper's investigation show that theologians can be emboldened to adopt panpsychism, without having to abandon a healthy respect for the conclusions of empirical research. The universe may just turn out to be more weird and wonderful yet.

\footnotetext{
${ }^{63}$ In addition, given the more widespread acceptance of panpsychism within Buddhism and Hinduism, this contemporary philosophical revival may aid in inter-religious as well as interdisciplinary dialogue, although this is beyond the scope of this paper's investigation.
} 